\title{
1 The cambial response of Scots pine trees to girdling and water stress
}

2 Marek Fajstavr ${ }^{1,4^{*}}$, Kyriaki Giagli ${ }^{1}$, Hanuš Vavrč́k ${ }^{1}$, Vladimír Gryc ${ }^{1}$, Petr Horáček ${ }^{4}$, Josef Urban ${ }^{2,3}$

3 'Department of Wood Science and Technology, Faculty of Forestry and Wood Technology, Mendel University

4 in Brno, Zemědělská 3, 61300 Brno, Czech Republic

$5 \quad{ }^{2}$ Department of Forest Botany, Dendrology and Geobiocenology, Faculty of Forestry and Wood Technology,

6 Mendel University in Brno, Zemědělská 3, 61300 Brno, Czech Republic

$7 \quad{ }^{3}$ Siberian Federal University, Svobodnyj Prospect 79, Krasnoyarsk, 660041 Krasnoyarsk, Russia

$8{ }^{4}$ Department of xylogenesis and biomass allocation, Domain of environmental effects on terrestrial ecosystems,

9 Czechglobe - Global Change Research Institute, The Czech Academy of Sciences, Belidla 4a, 60300 Brno,

10 Czech Republic.

11 *Corresponding author: e-mail: fajstavr.marek@seznam.cz, tel.: +420 739313583

12 ABSTRACT

We monitored six healthy dominant trees and six girdled Scots pine trees for two

14 successive growing seasons (2014 and 2015) to investigate the seasonal dynamics, cambial

15 activity, and morphology of the new xylem and phloem cells formed under environmental

16 stress when girdling was applied during the dormant period (15 January 2014). Microcore (1.8

$17 \mathrm{~mm}$ ) samples were collected weekly using a Trephor tool above and below the girdling area,

18 and weather data were measured on site. Drought stress in combination with girdling reduced

19 the total number of differentiation days cell formation. In 2014, no significant differences in

20 tracheid dimensions were observed between the girdled area and the control trees, while in

212015 , the control trees showed significantly smaller cell wall thickness and radial dimensions

22 of the latewood tracheids (LW) compared to 2014 and girdled trees had no occurrence of LW.

23 Under stressful heat waves and prolonged periods of no precipitation, the trees tended to

24 reduce the number of tracheids that were formed and exhibited smaller radial dimensions

25 (narrower tree rings) to increase their hydraulic efficiency. Trees responded to limited water 
availability by forming intra-annual density fluctuations (IADFs $L$ ) in the zone of the LW to overcome stressful conditions. Although xylem cell differentiation was affected by stressful conditions, no significant variability in phloem cell dimensions was observed. Thus, the phloem tissue was less sensitive to exogenous factors.

Keywords: Cell wall thickness, phloem, radial dimension, Pinus sylvestris L., tracheid, xylem, differentiation.

\section{INTRODUCTION}

The xylem formation process is described by five successive differentiation stages, including cell division (embryonic stage), cell enlargement (volume growth), cell wall thickening, lignification (maturation), and programmed cell death (Rossi et al. 2014). This process is a complex result of various interacting factors, i.e., water availability, temperature, nutrients, hormones, and genetic predisposition (Hölttä et al. 2010; Zhang et al. 2014; Fischer et al. 2019). For instance, the cell enlargement stage is affected by the process when several vacuoles cumulate into one large central vacuole whose uptake of water becomes intensive. The enlarging tracheids reach their final radial diameter during this stage, and therefore, the amount of water supply is a regulating factor for the size of the radial cell dimension (Wodzicki 1971; Kozlowski et al. 1991; Plomion et al. 2001). On the other hand, the final thickness of the cell wall of tracheids is known to be related to the air temperature, assimilate transport and rate of carbon allocation during the secondary cell wall thickening stage (sink activity) (Larson 1967; Körner 2015; Fonti \& Babushkina 2016; Castagneri et al. 2017). Generally, thin-walled earlywood (EW) tracheids with large radial dimensions require longer enlargement stages. In contrast, the thick-walled latewood (LW) tracheids with small radial dimensions remain in the secondary cell wall thickening and lignification stage longer, which predisposes them to their final dimensions. Cartenì et al. (2018) explained that at the 
beginning of the growing season, low sugar availability in the cambium causes slow wall deposition, resulting in a longer enlargement time; hence, EW (large cells with thin walls) is formed. High sugar availability during late summer/early autumn forms the LW (narrower cells with thick cell walls).

In the case of phloem, the annual increment is formed by early (EP) and late phloem (LP) sieve cells. The cambial zone on the phloem side always divides less compared to xylem, explaining the considerable disproportion existing between phloem and xylem tissues (Plomion et al. 2001). Gričar \& Čufar (2008) described the determination of the growth ring boundaries, reporting that the tangential walls of the first formed EP sieve cells adjacent to the previous year's crushed sieve cells have a slightly convex shape. As in xylem, the conductive capacity of phloem cells is affected not only by their anatomical structure (conduit size and number) but also by their sieve pore size and frequency along the pathway. Nevertheless, their development is primarily influenced by endogenous factors and less dependent on environmental factors compared to xylem cell growth (Gričar \& Čufar 2008; Mullendore et al. 2010).

Scots pine species have no typical collapsed phloem sieve cells from the previous year, which is common in many other coniferous species; thus, the boundary between newly formed and old growth sieve cells is detectable by the increased number of newly forming EP cells (Panshin \& De Zeeuw 1980; Larson 1994; Kozlowski \& Pallardy 1997; Gričar et al. 2016; Fajstavr et al. 2017). Furthermore, Gričar et al. (2016) found that trees with indistinguishable growth ring boundaries of phloem (i.e., Pinus halepensis Mill. and partly Pinus sylvestris L.) grow particularly well in the Mediterranean area. It was confirmed that stable phloem formation patterns and structures could be found only in trees of similar age, position in stands, vigour and vitality, which represents trees growing in similar environments, while LP is more variable than EP (Gričar et al. 2014b; Gričar et al. 2015). 
The drought events that have often occurred in temperate forests in recent decades are currently considered to be a global issue that can potentially affect the forest cover over large territories in a significant way (Christensen 2007). Intermittencies of the cambial activity during the growing season (caused by fluctuations in the temperature and tree water availability) are responsible for the deviations from the "normal" succession of the EW and LW zones. However, the limited photosynthesis caused by defoliation (biotic or abiotic origin) could also be another influencing factor (De Micco et al. 2016). The occurrence of intra-annual density fluctuations (IADFs) has been studied mostly in Mediterranean ecosystems, but IADFs have also been observed in other environments (e.g., temperate, boreal, and tropical ecosystems) affected by different environmental conditions (De Micco et al. 2016). A lack of water supply hinders the physiological functions of trees, causing dieback and mortality. Changes in carbon dynamics closely related to wood anatomical features have been observed (Fonti et al. 2010; McDowell 2011; Pellizzari et al. 2016). Drought-stressed conifer species in non-carbon-limited conditions usually form thick cell walls (DeSoto et al. 2011; Bryukhanova \& Fonti 2013; Liang et al. 2013), while Scots pine trees undergoing drought reduce the carbon costs of their water conducting system by decreasing the number and cell wall thickness of tracheids and proportionally increasing the lumen diameter (Eilmann et al. 2009). Hence, the analysis of xylem cell dimensions can provide useful information on tree responses to extreme drought stress (Fonti et al. 2010; Pellizari et al. 2016).

Knowledge of tree survival mechanisms and the underlying processes leading to death due to stress factors is a useful tool for physiologists, ecologists and foresters. One of the most commonly used methods for artificially inducing stress is the girdling of the stem (Stone 1974; Wilson 1998). The method is mainly used in the fields of horticulture and landscaping (reproduction control, fructification increase) for deciduous and evergreen tree species (Lewis 
\& McCarty 1973; Day \& DeJong 1999; Rivas et al. 2008). Girdling consists of the removal of

101 a complete strip of bark (phloem and cambium) from around the entire circumference of the stem at breast height $(1.30 \mathrm{~m})$, interrupting the supply of plant hormones and photosynthesis

103 products into the root system (Jordan \& Habib 1996; Tombesi et al. 2014). Girdled trees often

104 also suffer from a significant reduction in the water supply from the root system (Noel 1970;

105 Taylor 2002; Domec \& Pruyn 2008). This fatally affects the dynamics of cambial activity,

106 tree-ring width (number of cells), the proportion of LW within the tree ring, and eventually

107 wood density (Wilson \& Gartner 2002; Domec \& Pruyn 2008; Sellin et al. 2013). Fajstavr et

108 al. (2017) found that below the stem girdling area, typical thick-wall LW tracheids were never

109 formed, while above the stem girdling area, cell formation and tissue differentiation

110 continued, until the end of the growing season, at a less vigorous rate compared with the 111 control trees.

112 The ability of a tree to adapt to the environment can be assessed by analysing xylem

113 and phloem formation processes, especially under stressful conditions (Denn \& Dodd 1981;

114 Sass \& Eckstein 1995). When the girdling method was used to disrupt assimilation flow in the 115 mid-growing season (July 15), both cambial activity and cell formation stopped two weeks

116 after the applied treatment (Fajstavr et al. 2017). Following this research, we investigated the

117 impact of girdling stress on cambial activity and cell formation when applied before the

118 upcoming growing season (January 15). Under this prism, the basic hypothesis of this study

119 was established; girdling applied during the dormant period (January 15) will modify the

120 reactivation of cambial activity and cell formation in comparison with healthy trees (2014)

121 while promoting adaptation to drought stress. The analysis was focused on the (i) seasonal

122 dynamics of the cambial activity, (ii) timings of xylem and phloem formation, and (iii)

123 evaluation of the morphometric traits of the tracheids and sieve cells in the xylem and phloem 
124 increment formed in 2014 and 2015, when healthy and girdled Scots pine trees were growing

125 under a stressful environment (precipitation deficit combined with heat waves).

126

127

128

129

130

131

132

133

134

135

136

137

138

139

140

141

142

143

144

145

146

147

\section{MATERIALS AND METHODS}

\section{Site characteristics}

Twelve healthy dominant Scots pines (Pinus sylvestris L.) trees growing in the territory of the "Training Forest Enterprise Masaryk Forest Křtiny”, in Soběšice, Brno $\left(49^{\circ} 15^{\prime} 39^{\prime \prime} \mathrm{N}, 16^{\circ} 36^{\prime} 20^{\prime \prime}\right.$ E, 404 m a. s. 1., Czech Republic) were monitored. The forest in

Soběšice consists mostly of planted Scots pine trees (70\%) mixed with European larch and deciduous tree species. The soil type is categorized as mesotrophic Cambisol. The selected Scots pine trees were approximately 80 years old and $25 \mathrm{~m}$ tall on average, while the stem diameter at breast height was found to be $36 \pm 7 \mathrm{~cm}$. Six of the selected trees were used as control trees, while the remaining six trees were girdled. The girdling was performed before the onset of the growing season of the first studied year (January 15, 2014). The trees were girdled at breast height $(\mathrm{h}=1.30 \mathrm{~m})$ by removing a wide strip of bark $(7-10 \mathrm{~cm})$ including the phloem and cambial zone around the entire circumference of the stem.

\section{Weather data}

Average daily air temperature, daily precipitation totals, average daily soil water potential and the daily sum of the effective temperature were calculated. Air temperature (Minikin TRH, EMS Brno, Czech Republic), precipitation totals (MetOne Instruments, Grants Pass, Oregon, USA) and soil water potential (GB-2, Delmhorst Inc., Towaco, NJ, USA attached to an SP3 data logger, EMS Brno, Czech Republic) data were obtained directly on site. The soil water potential above -1.1 MPa (technical limit of the device) was measured at depths of $15 \mathrm{~cm}, 50 \mathrm{~cm}$, and $90 \mathrm{~cm}$ in two repetitions. Data were acquired every 10 minutes. Additionally, the sum of effective temperatures $\left(\Sigma_{\mathrm{ET}}\right)$ was estimated each day (Figs. 2c \& d). 
148 This cumulative value was obtained as the sum of all temperatures exceeding the set threshold

149 - the active zero $\left(\geq 5^{\circ} \mathrm{C}\right)$ (Fajstavr et al. 2017). The acquired weather data were compared

150 with the long-term average values (Climate Research Unit Time Series, CRU TS3.23; via

151 http://climexp.knmi.nl).

\section{Sampling}

153 Microcores with a thickness of $1.8 \mathrm{~mm}$ were collected at weekly intervals (from mid-

154 March until mid-November) by using the Trephor increment borer (Rossi et al. 2006). From

155 the control trees, microcores were obtained circumferentially starting from breast height. The

156 distance between individual sampling points was more than $2 \mathrm{~cm}$ to avoid wound tissue

157 during sampling (Fajstavr et al. 2017). In the case of the girdled trees, we took samples from

158 two different areas - from the area above the girdling (AGA) and the area below the girdling

159 (BGA), keeping the minimum distance of $20 \mathrm{~cm}$ from the removed strip.

\section{Sample preparation}

Microcores were immersed in FAA $(90 \mathrm{ml}$ of $70 \%$ ethanol, $5 \mathrm{ml}$ of acetic acid

solution, $5 \mathrm{ml}$ of $36-38 \%$ formaldehyde) immediately after sampling. One week later, the samples were rinsed in water and stored in ethanol (70\%). Thereafter, the microcores were

164 dehydrated in an ethanol series $(70 \%, 90 \%, 95 \%$, and $100 \%)$ and embedded in paraffin using

165 a tissue processor (Leica TP1020). Transverse sections were cut (8-12 $\mu \mathrm{m}$ thick) with a rotary

166 microtome and then dried in a laboratory oven $\left(70{ }^{\circ} \mathrm{C}\right.$ for 20 minutes $)$. The microsections

167 were first rid of the paraffin content (Bio Clear, Bio Optica, Milano, Italy) and then

168 selectively stained by safranin $(0.04 \%)$ and Astra blue $(0.15 \%)$ dyes (van der Werf et al.

169 2007) to distinguish the lignin and cellulose contents. Finally, permanent sections were

170 prepared using Euparal mounting medium (Waldeck, Münster, Germany) (Gričar et al. 2014;

171 Fajstavr et al. 2017). 


\section{Measurements and data processing}

A light microscope (Leica DMLS, including a polarisation filter) with an attached digital camera (Leica DFC 280) was used to analyse the cambial activity and the process of xylem and phloem cell formation. During both growing seasons, the numbers of cells in the cambial zone (CC, Fig. 3), tracheids in the phase of cell enlargement (PC; Fig. 3c), secondary cell wall thickening (SW; Fig. 3c), mature tracheids (MT; Fig. 3c), sieve cells in the early phloem (EP; Fig. 3b; Figs. 3c \& e) and late phloem formation (LP; Figs. 3c \& e) were counted in three files within the weekly interval (Deslauriers et al. 2008; Fajstavr et al. 2017). The border between the PC and SW phases was distinguished by glistening secondary cell walls under a polarisation filter, and the EP and LP sieve cells were determined by the layer of axial parenchyma (red filled cell lumens as dyed by safranin solution) (Fig. 3e).

The types of the cells were determined according to the following rules. The dormant

CCs were identified by their narrow radial dimensions (flattened rectangular shaped cells) and thin, nonlignified primary cell walls (blue-stained). The newly formed EP sieve cells and enlarging xylem cells were distinguished by their radial dimensions that were two times larger than the those of the flattened cambial cells. The fully formed xylem cells were determined by their thick, lignified cell walls (red-stained) and empty lumen. The phloem sieve cells were distinguished by their thin, nonlignified, blue-stained cell walls with a round to irregular shape. The cell walls of the sieve cells were slightly thicker than those of the CC. The EP sieve cells were larger than the LP considering their radial dimensions (Gričar et al. 2016).

The marginal zone between the old and newly formed phloem increment was detected and counted by the increasing number of newly formed large cells in comparison with the measured increment of the previous year (Fajstavr et al. 2017). Following Gričar \& Čufar (2008), we determined the first phloem cells by their slightly rounded thin tangential walls and differentiated phloem cells into EP and LP sieve cells, which were separated by an axial 
197

parenchyma band. The beginning of cambial activity was defined when the $\mathrm{CC}$ gradually began to divide (metabolically active) and hence increase in number (Fig. 3b) (Prislan et al. 2016; Fajstavr et al. 2017).

Four IADFs types were monitored and classified in line with the literature (Campelo et al. 2007; De Micco et al. 2016): EW (E and E+) and LW (L and L+). Type "E" occurs in the first half of the growing season as a zone of LW-like tracheids in the EW, type "E+" occurs at the end of the EW as transition tracheids between real EW and LW, type "L" is formed during the second half of the growing season as EW-like tracheids in the LW, and type "L+" occurs between the LW and EW of the next growing season as a zone of EW-like tracheids with narrower lumen and thicker cell walls than real EW tracheids and is similar to the transition zone between EW and LW tracheids (De Micco et al. 2016).

The morphological parameters of cells were analysed in the last formed tree ring, where three radial files of xylem and phloem cells were selected (Deslauriers et al. 2008). The morphological parameters of cells (cell wall thickness, radial dimension of the cell lumen, total radial dimension of cells, total number of formed cells) were measured by ImageJ software (Abramoff et al. 2005).

Mork's criterion was used to distinguish EW from LW (Denne 1988). According to Mork (1928), when the double cell wall thickness is larger than the cell lumen diameter, the cell is recorded as LW (Fig. 1). To calculate the total radial dimension of one cell, we used equation 1:

218 where $R$ is the total cell radial dimension, $2 C W$ is the thickness of a double cell wall, and $L$ is the cell lumen width. 
equation 2:

where $X_{n}$ is the rank of the cell in the tree ring (increment) and $N$ is the total number of cells.

In due course, we investigated the differences between control and girdled trees (only in the AGA). In the BGA, cambium did not activate during any of the examined years. Hence, the analysis was performed between two groups (AGA and control trees). The differences between years (2014 and 2015) and samples in the listed xylem and phloem anatomical variables were determined using individual one-way repeated measures analysis of variance (ANOVA, $\alpha=0.05$ ).

The Kruskal-Wallis test $(\alpha=0.05)$ was used for testing ( $p$-values), assuming that the 231 samples had equal mean values since the dataset did not fit ANOVA's assumptions. The 232 Kruskal-Wallis test was performed in R software.

234 (Rossi et al. 2003). The model ( $1^{\text {st }}$ derivatives) estimated the daily number of cells formed per 235 year, as described by equation 3:

237 where $y$ is the cumulative value of the number of cells in one week, $t$ is the day of the year, $238 A$ is the upper asymptote of the maximum number of cells, $\beta$ is the parameter location along 239 the $\mathrm{x}$-axis, and $\kappa$ is the inflection point on the curve representing the maximum daily 240 increment of cells. 
stage, b) the duration of the PC stage, and c) the time that a given cell spent at the SW and

244 MT stages together, up to the stage of a fully matured cell wall. This model was used in the context of all sample trees, and averages for all trees were evaluated in this way. The analysis was used for the comparison between cells in particular portions (quarters) of fully formed 247 annual rings of individual analysed trees.

\section{RESULTS}

\section{Weather conditions}

The examined years 2014 and 2015 were both found to be drier than the long-term 251 average values, mostly due to low precipitation during the spring of both years (Table 1). The year 2015 was drier than 2014 in all seasons. The lack of precipitation in 2015 was combined with high average daytime temperatures (during summer months). This finding was confirmed by the sum of effective temperatures as well as the soil water potential (Table $1 \&$ 255 Fig. 2).

\section{Cambial activity and cell formation}

Significant differences between the AGA and control trees were observed during the onset $(p=0.006)$ as well as the end $(p=0.013)$ of cambial activity in 2014 (Table 2$)$. The onset of cambial activity in the AGA $\left(\Sigma_{\mathrm{ET}}=57.9^{\circ} \mathrm{C}\right)$ was recorded one week earlier (March 21 , DOY $80 \pm 3)$ than in the control trees $\left(\Sigma_{\mathrm{ET}}=77.1^{\circ} \mathrm{C}\right)$, which was 65 days after girdling 261 was performed (65 dAPG). The rest of the monitored differentiation stages had nearly 262 identical courses for both groups (Table 2). The first xylem cells at the PC stage were formed during the first week of April $\left(\Sigma_{\mathrm{ET}}=107.9^{\circ} \mathrm{C}\right)$ in both groups $(78 \mathrm{dAPG})$, and the first fully

264 lignified tracheids were observed one month later (112 dAPG) in the first week of May 2014

$265\left(\Sigma_{\mathrm{ET}}=309.9{ }^{\circ} \mathrm{C}\right)$. This observation coincided with the intensive period of cambial activity, 266 i.e., the cambial zone consisted of more than 8 cells during May (Fig. 5a). In mid-June (150 
dAPG), a sudden reduction in the number of cambial cells was recorded after 16 days of no precipitation and notably increased average daily temperatures (Figs. 2a \& b). In due course, when the precipitation totals increased again (early August), we noticed that cambium was reactivated once again (Fig. 5a). This phenomenon affected all differentiation stages (Figs. 5c $\&$ e), initiating the formation of the IADFs.

Regarding phloemogenesis, a significant difference $(p=0.039)$ was detected between the two sample groups during the time of EP formation (Table 2), which was reflected in the difference in the total duration of phloem cell formation $(p=0.046)$.

In 2015, no significant difference (Table 2) was found at the beginning of cambial activity $\left(\Sigma_{\mathrm{ET}}=29.3^{\circ} \mathrm{C}\right)$ between the examined groups, since the activity occurred in the same week (435 dAPG). However, a significant difference was found in the timing of differentiation stages, excluding the beginning of the PC stage (Table 2). In the first week of April 2015, the sum of effective temperatures was only $30.7^{\circ} \mathrm{C}$, which was approximately 70 ${ }^{\circ} \mathrm{C}$ less than that in the previous year (Fig. $2 \mathrm{~d} \&$ Table 2). The first fully lignified tracheids appeared in the control trees on May 19, 2015 (DOY $139 \pm 6, \Sigma_{\mathrm{ET}}=323.6{ }^{\circ} \mathrm{C}$ ), i.e., which was more than a week earlier than in the AGA. The number of cells in the cambium zone (9-11) was the highest in both tree groups during May, but due to drought stress (Figs. $2 b$ \& d), the cambial activity of the control trees finished in the first half of August, which was over one month later than in the AGA case (540 dAPG).

The drought stress in 2015 also influenced the length of phloem formation in the AGA, which significantly differed from that in the control trees. Namely, the phloem formation lasted until only the first half of June $(p=0.003)$ in the AGA, significantly affecting the LP formation time $(p=0.009)$ and hence shortening the duration of phloemogenesis compared to that in the control trees $(p=0.011$, Table 2$)$. 
The Gompertz function model showed that the total annual radial increment of xylem and phloem in 2014 did not differ significantly between the AGA and control trees, but only the increment of the AGA was of high intensity (Table 3; Figs. 5q \& s).

In 2015, there was a significant reduction in the number of xylem cells in the total increment of both the AGA (by approximately 10 tracheids) and the control trees (by approximately 20 tracheids) compared to the number of cells in 2014 (Table 3; Figs. 4c \& d; Fig. 5r). The daily cell production rate was nearly the same in both sample groups this year. Nevertheless, only half of the xylem cells were formed in the AGA compared with that in the control trees. Additionally, the total duration of xylem cell production was 50 days shorter in the AGA according to the Gompertz function.

At the same time, the final number of cells in the phloem growth ring, as well as the rate of phloem cell production, was twice as high compared to that in the AGA (2015). Interestingly, the day when the maximum increment occurred coincided in both studied groups (DOY 108, Table 3). The number of days it took to form all phloem cells was only 5 days higher for the control trees.

\section{Kinetics/timing of tracheid development}

In 2014 , although the first $50 \%$ of tracheids formed in both examined groups followed a similar course of differentiation, the formation of the following half of tracheids was significantly different in the AGA (Table 4; Figs. 6a \& b). First, their tracheids differed significantly both at the PC stage $(p=0.002)$ and throughout the duration of differentiation $(\mathrm{PC}+\mathrm{SW}, p=0.012)$ in the third quarter of the tracheids that were formed. Furthermore, a significant difference was observed mainly in the last quarter of tracheids that were formed (Fig. $6 \mathrm{~b} \&$ Table 4$)$ at the PC stage $(p=0.000)$ and SW stage $(p=0.000)$. The total differentiation time of the last quarter of tracheids was more than twice as fast in the AGA as that in the control trees $(p=0.003)$. 
All tracheids formed in the control trees remained at the SW stage longer than at the

318 PC stage, while in the AGA, the ratio was balanced (Table 4; Figs. 6c \& d). Dividing the

319 tracheid formation into quarters, we noticed that the first quarter of tracheids that were formed

320 by both groups had initially almost the same rate of differentiation (Table 4), but the

321 remaining tracheids differed between the two groups. In the second quarter, the differences

322 were observed in $25-50 \%$ of the tracheids, since the AGA spent a significantly more days ( $p$

$323=0.000)$ at the PC stage and half as many days at the SW stage $(\mathrm{p}=0.000)$ compared to the

324 control trees. In the third quarter of the tracheids that were formed, the AGA differed

325 significantly at the SW stage $(p=0.000)$, resulting in reduced overall differentiation time (PC

$326+\mathrm{SW})$ by up to 10 days $(\mathrm{p}=0.002)$ in comparison with the control trees (Fig. $6 \mathrm{~d} \&$ Table 4$)$.

327 Finally, the last quarter of the tracheids that were formed by the AGA completed with almost

328 one week longer total differentiation time than that in the control trees (Fig. $6 \mathrm{~d} ; \mathrm{p}=0.005$ ).

329 The last quarter of tracheids in the control trees spent three times longer at the SW stage at the 330 expense of the PC stage (Fig. 6c).

\section{$331 \quad$ Morphometric traits of cells}

In 2014, the analysed morphometric parameters of tracheids depicted no notable

333 differences between AGA and control trees (Table 5). The tracheid double cell wall thickness

334 increased depending on the relative position of the tracheid in a tree ring (Fig. 7a). According

335 to the tracheid radial dimension curve, the greatest dimensions were observed in the first half

336 of the growing season, significantly decreased due to the IADFs appearance and then

337 increased again to the normal level (Fig. 7c). In 2014, the first differences between the

338 tracheid dimensions of AGA and the control trees began to occur in the last $25 \%$ of LW that

339 formed in AGA, which remained more than twice as short during the maturation (SW + MT)

340 stage (see Figs. $6 a \mathrm{a}$ b). Student's t-distribution revealed that the considerably shorter time

341 affected the formation of significantly thinner cell walls of these tracheids $(p=0.002$; Fig. 
4b). However, the tracheid radial dimensions did not differ between AGA and the control trees $(p=0.159)$.

In contrast to xylem cells, the morphometric parameters of sieve cells of phloem manifested very low variability in the relative position of the annual increment (Figs. 7e \& g). In 2015, significant differences were noted compared to 2014 as well as between the two groups (Figs. 7b \& d; Tables $5 \&$ 7). The dimensions of EW of control trees manifested hardly any changes in comparison with the previous year; on the other hand, we observed a significant reduction in all traits of LW (Table 5). The tracheid double cell wall dimensions of control trees in 2015 manifested significantly lower values in the second half of the growing season ( $0.6-0.8$ relative position in a tree ring), and in particular, there was not such a considerable variance among these values as in 2014 (Figs. 7a \& b). However, a significant reduction in the dimensions of both types of tracheids was recorded for the AGA (Figs. $4 \mathrm{~b} \&$ d). Namely, the radial dimensions of their EW and LW were reduced by over $10 \mu \mathrm{m}$ compared to those in 2014. A significant reduction was observed in the double cell wall thickness, especially in LW, in all AGA samples (Table 5). The dimensions of the double cell walls of AGA exhibited negligible variance in 2015, which was caused by the minimum representation of LW (Fig. 4d). Fig. 7d shows that the radial dimensions did not exhibit a fluctuating trend as in 2014. A significant difference in cell traits within the comparison between AGA and control trees in 2015 was proven for EW (Table 7) in terms of the total radial dimensions $(F=146.69 ; p=0.000)$, radial dimension of lumen $(F=123.20 ; p=0.000)$ and double cell wall thickness $(F=84.76 ; p=0.000)$. No significant differences were observed for LW in 2015 (Table 7). In line with 2014, the morphometric traits of sieve cells of phloem showed a very low variability in the RP of the annual increment again in 2015 (Figs. 7e \& g). However, 
significant differences were observed when the two groups of sample trees were compared as well as 2014 and 2015, in particular for the radial dimensions of LP (Tables 6, 7).

\section{DISCUSSION}

\section{Drought-stressed cambial phenology and IADFs formation}

The rate and duration of cambial derivative production affect the annual radial increment in trees. Cambial cell division directly affects the transport efficiency of water, mineral nutrients and photoassimilates, which are responsible for the formation of new xylem and phloem elements (Plomion et al. 2001; Sorce et al. 2013). Thus, the newly formed cells are driven by the dynamics of cambial phenology (Kozlowski et al. 1991; Larson 1994). Cambium cells and their divisional activity are influenced by changes in temperature (Kozlowski et al. 1991;

Deslauriers \& Morin 2005). In Pinus sylvestris L., temperature is found to influence cell production and differentiation at the earliest stage of formation (Wodzicki 1971).

In 2014, the timings of the xylem and phloem did not significantly differ, even though the cambial activity began and ceased earlier in the AGA than in the control trees. In contrast, in 2015, the finding was reversed, i.e., the onset of cambial activity and PC stage coincided in both groups, but all following stages were initiated with a significant delay in the AGA compared to that in the control trees. Additionally, phloem cell formation ceased significantly early in the AGA.

Since the precipitation amount in the III-V period (from March to May) did not differ much between the two years (Table 1), the air temperature was the parameter that presumably caused a delay of the PC stage (over 14 days on average) in comparison to the previous year. This effect was manifested in the delay of all differentiation stages, especially in the AGA. Nevertheless, the reactivation, duration, and cessation of cambial divisions are influenced by factors other than air temperature and precipitation, since different physiological processes may independently act in different phases of cell division and differentiation (Rossi et al. 
2003; Thibeault-Martel et al. 2008; Lupi et al. 2010). The effect of plant hormones (IAA indole-3-acetic acid) and carbohydrate allocation can play key roles during the reactivation of cambial cells and initiation of cell formation (Savidge \& Wareing 1982; Uggla et al. 1998; Sundberg et al. 2000, Sorce et al. 2013), especially by increasing carbohydrate accumulation above girdling during the absence of a root sink below girdling (Wilson 1968; Little et al. 1990; Sundberg et al. 1994; Domec \& Pruyn 2008). This factor probably affected the cambial reactivations in the AGA. The physiological changes that were observed (e.g., cell wall maturation) were probably affected by the increasing impact of drought stress in the rest of the growing season in 2015 .

The drought stress - alternation of precipitation episodes and long-lasting precipitation absence combined with heat waves caused a fast cambial temperature response (latency and subsequent reactivation), resulting in IADFs in all monitored years and both types of sample trees (Figs. 4a-c). Reduced cambial divisions (less than 7 cambial cells in the cambial zone) were observed when the average air temperature exceeded $25^{\circ} \mathrm{C}$ and the soil water potential values dropped below -1 MPa. In 2014, the number of cambial cells began to increase in the last week of July related to precipitation abundance after the water deficit during June. The thresholds of air temperature and soil water potential corresponded with the findings of Antonova \& Stasova $(1993,1997)$ and Myers \& Talsma (1992), respectively. Myers \& Talsma (1992) investigated the threshold regarding the wilting point (-1.5 MPa). Within the Pinus genus, the EW-like tracheids in the LW zone (IADFs $L$ ) are described as a reaction of favourable moisture conditions after the summer precipitation episode (Campelo et al. 2007; Novak et al. 2013; Carvalho et al. 2015), which matches our findings. According to Balzano et al. (2018), the EW-like tracheids in the LW zone (named L-IADFs) were formed in autumn when precipitation was abundant, particularly when the precipitation in October was more than double that in September. They also noted a double pause in cell production leading to L- 
IADFs as well. This effect strongly correlated with the double peaks of cambial production,

417 which coincides with our results (Fig. 5a \& Figs. 5c-f). matched the "IADFs $L$ " (Fig. 4a), and AGA seemed to be more similar to the " $L$ " at the end of 2014 (Fig. 4b), but the causality of tracheid differentiation is questionable. The effect (thinwalled LW tracheids) potentially originated from carbon starvation in response to a lack of

422 carbohydrate supply (Fig. 3g). In contrast with the control trees, AGA exhibited no response to precipitation episodes in mid-August 2015 (Figs. 5d \& f; Figs. 2b \& d); thus, the AGA did not reactivate their cambial activity, and the increment of typical thick-walled LW was not observed in 2015 (Fig. 4d). Nevertheless, the IADFs of control trees matched the IADFs $L^{+}$ definition (Figs. 4c \& e) rather than the significantly earlier cessation of cambial activity in mid-August 2015 (Fig. 5b \& Table 2).

The process triggering IADFs formation is linked with increased cell enlargement due to high turgor pressure resulting from high water availability after an abundant precipitation episode in autumn (Sperry et al. 2006; De Micco et al. 2016; Pacheco et al. 2016; Balzano et 431 al. 2018). The occurrence of IADFs is an adjustment response to the balancing between 432 hydraulic efficiency and hydraulic safety of water transport (De Micco et al. 2008, 2009) and 433 thereby indicates a more adaptive capacity to cope with changing water availability typical of

434 Mediterranean climates (Balzano et al. 2018).

\section{Differentiation timings of individual tracheids related to their dimensions}

$$
\text { Cuny et al. (2014) and Carvalho et al. (2015) stated that the tracheid's radial }
$$

437 dimension is strongly affected by the rate of cambial cell production. Furthermore, the more

438 intensive cell division involves narrower tracheid formation associated with a decrease in the 439 period spent in the cell enlargement stage. Under the increased rate of cambial division, the 440 newly divided cells pushed the previous cells out of the enlargement zone towards the cells in 
441 the wall thickening stage (Carvalho et al. 2015). This process is influenced by the width of the

442 auxin radial gradient, which determines the width of the cell enlargement zone (Uggla et al.

443 1996) and thus is affected by the time spent in the stage (Carvalho et al. 2015). Therefore, the

444 lumen diameter is not only determined by the soil water supply during the accumulation of

445 vacuoles (Kozlowski et al. 1991) but also influenced by the auxin gradient and the time spent

446 in the cell enlargement stage (Carvalho et al. 2015). In relation to the annual ring width,

447 Rathgeber et al. (2011) estimated that $75 \%$ of tree-ring width variability is attributable to the

448 rate of cell production, and only $25 \%$ is attributable to its duration.

In Soběšice, while the control trees differed only in their LW dimensions between 2014 and 2015, in the AGA, all tracheid dimensions were considerably reduced between the two observed years. At the beginning of 2015 , the first $25 \%$ of formed tracheids remained in both the enlargement and maturation (SW + MT) stages during the same period. Nevertheless, the remaining $50 \%$ of the formed tracheids remained for a shorter time $(\mathrm{SW}+\mathrm{MT})$. The IADFs formation changed the course of tracheid differentiation by decreasing the duration of the enlargement stage. The variation in the radial dimensions of tracheids depends on seasonal changes in the rate of growth during the cell enlargement stage (Wodzicki 1971). This probably occurred in our case during the IADFs $L$ formation after the summer precipitation episode.

\section{The causality of drought stress and tracheid dimensions}

461 (Dewar et al. 1994). The adaptation processes combined with reduced sink activity (Körner 462 2003) might also adjust the cell wall thickening process (Martin-Benito et al. 2013).

463 Therefore, the cell wall thickness is closely related to xylem carbon costs (Fonti et al. 2010), 464 which form half of the plant biomass (Körner 2015). Cuny et al. (2014) refuted the longlasting assumption that the increasing thickness of tracheids along the annual increment is 
driven by increased biomass fixation during the SW thickening process. Their findings revealed that the amount of material used for cell wall formation remained almost constant over the entire radial increment of formed tracheids. Additionally, they stated that cell size affects the changes in cell wall thickness. Therefore, the time spent in the cell enlargement stage contributes to $75 \%$ of the changes in cell size (Cuny et al. 2014). However, in Soběšice (2014), a significantly smaller cell wall thickness in the last $25 \%$ of formed tracheids of AGA was observed despite the radial dimension not differing from that in the control trees. The significant differences in tracheid dimensions found in the following year (2015) were probably caused by other stressful factors (e.g., IADFs, water deficit) and adaptation processes. During drought stress, trees respond by adjusting their carbon allocation to form reserves (Wiley \& Helliker 2012). In this study, it was not easy to clarify the influencing factors that had a droughttriggered effect on xylem cell differentiation related to tracheid dimensions. Even other authors revealed contrasting findings (Pellizzari et al. 2016). Bryukhanova \&Fonti (2013)

480 shared a statement with Liang et al. (2013) that a drought-reduced tracheid lumen leads to a 481 decline in stem hydraulic conductivity. In contrast, Eilmann et al. (2009) found that drought482 stressed pine trees significantly increased the radial dimension of tracheids as a result of 483 adaptation to a reduced conducting area (reduced number of tracheids). Hacke et al. (2001) 484 reported that a mechanism exists that decreases the lumen diameter of the tracheid to increase 485 hydraulic safety. According to De Micco et al. (2008, 2009), IADFs formation is a balancing 486 process between hydraulic efficiency and hydraulic safety. This parallel reduction in the 487 number of tracheids and their cell wall thickness (mainly in water-conductive EW) seems to 488 be forced by the limited carbon availability rather than the increased demand for hydraulic 489 safety (Fonti \& Babushkina 2016). However, Scots pine differs (Eilmann et al. 2009) from 
other drought-stressed coniferous plants, which form thicker cell walls to increase hydraulic safety (DeSoto et al. 2011; Liang et al. 2013).

During the two examined growing seasons (2014 and 2015), it was found that the cambial stress response altered the course of xylem formation. Furthermore, the cambial activity was significantly shortened in the AGA, and the IADFs formation influenced the duration of xylem cell differentiation, significantly affecting the final tracheid dimensions compared to those in the control trees. Although our primary hypothesis was confirmed, many interactive relationships affected xylem cell morphology during drought stress. Hence, it is difficult to determine whether cambial divisions directly drive cell dimensions.

\section{CONCLUSIONS}

In this study, considerable responses of cambial divisions to drought stress were found. These responses resulted in EW-like tracheid formation in the LW zone (IADFs $L$ ). Moreover, IADFs $L$ formation affected the course of differentiated timings of individual tracheids, which was reflected by significant differences in cell morphology. Namely, the xylem cells reflected the drought stress responses by changing their dimensions. In 2014, no significant differences in tracheid dimensions were observed between AGA and the control trees. The differences were obvious in 2015 when the control trees presented significantly smaller cell wall thickness and radial dimensions of the LW compared to those in 2014. Furthermore, the tracheid dimensions in the AGA were significantly smaller than those in both the control trees and the previous examined year. The phloem response to drought stress was also depicted by the reduction in the number of sieve cells, as well as the duration and cessation time of their annual formation. However, the phloem cells showed a rather more homogenous structure (low variability of dimensions) compared to the xylem cells. Thus, the phloem tissue seemed to be less sensitive to exogenous factors. 
515 of formed tracheids (narrower tree ring) and relatively decreased their radial dimensions to 516 increase hydraulic efficiency. During the combination of stressful heat waves and prolonged

517 periods of precipitation absence, this process could compensate for the adaptability to water 518 deficits by forming the IADFs $L$ in the zone of the LW. The formation of IADFs $L$ could 519 support the function of the hydraulic conductive zone to overcome the stressful conditions. In 520 the case of girdled trees, the anatomical changes potentially originated from Eilman's 521 assertion as one of the dieback processes, but this needs to be elucidated by further research.

\section{ACKNOWLEDGEMENTS}

This experimental research was supported by the Internal Grant Agency of Faculty of

524 Forestry and Wood Technology (IGA, 42/2014 and IGA LDF, LDF_VP_2016014), European

525 Social Fund and the state budget of the Czech Republic CzechGlobe - Global Change

526 Research Institute of the Czech Academy of Sciences (GCRI). This work was supported by

527 the Ministry of Education, Youth and Sports of CR within the National Sustainability

528 Program I (NPU I), grant number LO1415 and the Russian Science Foundation [Project 18-

$52974-10048$, The anatomical and physiological response of Scots pine xylem formation to

530 variable water availability]. Also, we would like to thank Věra Kolářová for the correction of

531 the English writing style and anonymous reviewers for their valuable comments and

532 suggestions for improving the quality of the paper. In addition, we would like to thank the

533 “American Journal Experts" professional copy-editing service for certifying the quality of the 534 language.

\section{REFERENCES}


Antonova GF \& Stasova VV. 1997. Effects of environmental factors on wood formation in larch (Larix sibirica Ldb.) stems. Trees - Struct. Funct. 11: 462-468. https://doi.org/10.1007/p100009687

Antonova GF \& Stasova VV. 1993. Effects of environmental factors on wood formation in Scots pine stems. Trees V. 7. N. 4. P. 214-219. https://doi.org/10.1007/BF00202076

Abramoff MD, Magalhães PJ \& Ram SJ. 2005. Image processing with ImageJ Part II. Biophotonics. Int. 11: 36-43.

Balzano A, Čufar K, Battipaglia G, Merela M, Prislan P, Aronne G \& De Micco V. 2018. Xylogenesis reveals the genesis and ecological signal of IADFs in Pinus pinea L. and Arbutus unedo L. Ann. Bot. 121(6): 1231-1242. https://doi.org/10.1093/aob/mcy008

Bryukhanova M \& Fonti P. 2013. Xylem plasticity allows rapid hydraulic adjustment to annual climatic variability. Trees - Struct. Funct. 27: 485-496. https://doi.org/10.1007/s00468-012-0802-8

Campelo F, Nabais C, Freitas H \& Gutiérrez E. 2007. Climatic significance of tree-ring width and intra-annual density fluctuations in Pinus pinea from a dry Mediterranean area in Portugal. Ann. For. Sci. 64: 229-238. https://doi.org/10.1051/forest:2006107

Cartenì F, Deslauriers A, Rossi S, Morin H, De Micco V, Mazzoleni S \& Giannino F. 2018. The Physiological Mechanisms Behind the Earlywood-To-Latewood Transition: A Process-Based Modeling Approach. Front. Plant Sci. 9: 1053. https://doi.org/10.3389/fpls.2018.01053

Carvalho A, Nabais C, Vieira J, Rossi S \& Campelo F. 2015. Plastic response of tracheids in Pinus pinaster in a water-limited environment: Adjusting lumen size instead of wall thickness. PLoS One 10: 1-14. https://doi.org/10.1371/journal.pone.0136305 
Castagneri D, Fonti P, Von Arx G \& Carrer M. 2017. How does climate influence xylem morphogenesis over the growing season? Insights from long-Term intra-ring anatomy in Picea abies. Ann. Bot. 119: 1011-1020. https://doi.org/10.1093/aob/mcw274

Christensen JH. 2007. Regional Climate Projections. Clim. Chang. Phys. Sci. Basis. 27: 847940.

Cuny HE, Rathgeber CBK, Frank D, Fonti P \& Fournier M. 2014. Kinetics of tracheid development explain conifer tree-ring structure. New Phytol. 203: 1231-1241. https://doi.org/10.1111/nph.12871

Day KR \& DeJong TM. 1999. Improving fruit size: thinning and girdling nectarines, peaches and plums. Compact Fruit Tree 32: 49-51.

De Micco V, Aronne G \& Baas P. 2008. Wood anatomy and hydraulic architecture of stems and twigs of some Mediterranean trees and shrubs along a mesic-xeric gradient. Trees 22: 643-655. https://doi.org/10.1007/s00468-008-0222-y

De Micco V \& Aronne G. 2009. Seasonal dimorphism in wood anatomy of the Mediterranean Cistus incanus L. subsp. incanus. Trees 23: 981-989. https://doi.org/10.1007/s00468009-0340-1

De Micco V, Campelo F, De Luis M, Bräuning A, Grabner M, Battipaglia G \& Cherubini P. 2016. Intra-annual density fluctuations in tree rings: how, when, where, and why? IAWA J. 37(2): 232-259. https://doi.org/10.1163/22941932-20160132

Denn MP \& Dodd RS. 1981. The environmental control of xylem differentiation. In: Barnett JR, ed. Xylem cell development. Kent, UK: Castle House 236-255.

Denne MP. 1988. Definition of Latewood According to Mork (1928). IAWA J. 10: 59-62. https://doi.org/10.1163/22941932-90001112 
Deslauriers A \& Morin H. 2005. Intra-annual tracheid production in balsam fir stems and the effect of meteorological variables. Trees - Struct. Funct. 19: 402-408. https://doi.org/10.1007/s00468-004-0398-8

Deslauriers A, Rossi S, Anfodillo T \& Saracino A. 2008. Cambial phenology, wood formation and temperature thresholds in two contrasting years at high altitude in southern Italy. Tree Physiol. 28: 863-871. https://doi.org/10.1093/treephys/28.6.863

DeSoto L, De la Cruz M \& Fonti P. 2011. Intra-annual patterns of tracheid size in the Mediterranean tree Juniperus thurifera as an indicator of seasonal water stress. Can. J. For. Res. 41: 1280-1294. https://doi.org/10.1139/x11-045

Dewar RC, Ludlow AR \& Dougherty PM. 1994. Environmental Influences on Carbon Allocation in Pines. Ecol. Bull. 43: 92-101.

Domec J-C \& Pruyn ML. 2008. Bole girdling affects metabolic properties and root, trunk and branch hydraulics of young ponderosa pine trees. Tree Physiol. 28: 1493-1504. https://doi.org/10.1093/treephys/28.10.1493

Eilmann B, Zweifel R, Buchmann N, Fonti P \& Rigling A. 2009. Drought-induced adaptation of the xylem in Scots pine and pubescent oak. Tree Physiol. 29: 1011-1020. https://doi.org/10.1093/treephys/tpp035

Fajstavr M, Giagli K, Vavrčík H, Gryc V \& Urban J. 2017. The effect of stem girdling on xylem and phloem formation in Scots pine. Silva Fenn. 51. https://doi.org/10.14214/sf.1760

Fajstavr M, Paschová Z, Giagli K, Vavrčík H, Gryc V \& Urban J. 2018. Auxin (IAA) and soluble carbohydrate seasonal dynamics monitored during xylogenesis and phloemogenesis in Scots pine. IForest - Biogeosciences For. 11: 553-562. https://doi.org/10.3832/ifor2734-011 
606 Fischer U, Kucukoglu M, Helariutta Y \& Bhalerao RP. 2019. The Dynamics of Cambial Stem

607

608

609

610

611

612

613

614

615

616

617

618

619

620

621

622

623

624

625

626

627

628 Cell Activity.Annu. Rev. Plant Biol. 70: 293-319. https://doi.org/10.1146/annurevarplant-050718-100402

Fonti P, Von Arx G, García-González I, Eilmann B, Sass-Klaassen U, Gärtner H \& Eckstein D. 2010. Studying global change through investigation of the plastic responses of xylem anatomy in tree rings. New Phytol. 185: 42-53. https://doi.org/10.1111/j.14698137.2009.03030.x

Fonti P \& Babushkina EA. 2016. Tracheid anatomical responses to climate in a forest-steppe in Southern Siberia. Dendrochronologia 39: 32-41. https://doi.org/10.1016/j.dendro.2015.09.002

Harris I, Jones PD, Osborn TJ \& Lister DH. 2014. Updated high-resolution grids of monthly climatic observations - the CRU TS3.10 Dataset. Int. J. Climatol. 34: 623-642. https://doi.org/10.1002/joc.3711

Gričar J \& Čufar K. 2008. Seasonal dynamics of phloem and xylem formation in silver fir and Norway spruce as affected by drought. Russ. J. Plant Physiol. 55: 538-543. https://doi.org/10.1134/S102144370804016X

Gričar J, Prislan P, Gryc V, Vavrčík H, De Luis M \& Čufar K. 2014. Plastic and locally adapted phenology in cambial seasonality and production of xylem and phloem cells in Picea abies from temperate environments. Tree Physiol. 34: 869-881. https://doi.org/10.1093/treephys/tpu026

Gričar J, Jagodic ŠS, Šefc B, Trajković J \& Eler K. 2014b. Can the structure of dormant cambium and the widths of phloem and xylem increments be used as indicators for tree vitality? Eur. J. Forest Res. 133: 551-562. https://doi.org/10.1007/s10342-014-0784-8 
Gričar J, Prislan P, de Luis M, Gryc V, Hacurová J, Vavrčík H \& Čufar K. 2015. Plasticity in variation of xylem and phloem cell characteristics of Norway spruce under different local conditions. Front. Plant Sci. 6: 1-14. https://doi.org/10.3389/fpls.2015.00730

Hacke UG, Sperry JS, Pockman WT, Davis SD \& McCulloh KA. 2001. Trends in wood density and structure are linked to prevention of xylem implosion by negative pressure. Oecologia 126: 457-461. https://doi.org/10.1007/s004420100628

Hölttä T, Mäkinen H, Nöjd P, Mäkelä A \& Nikinmaa E. 2010. A physiological model of softwood cambial growth. Tree Physiol. 30: 1235-1252. https://doi.org/10.1093/treephys/tpq068

Jordan M-O \& Habib R. 1996. Mobilizable carbon reserves in young peach trees as evidenced by trunk girdling experiments. J. Exp. Bot. 47: 79-87. https://doi.org/10.1093/jxb/47.1.79

Körner C. 2003. Carbon limitation in trees. J. Ecol. 91: 4-17. https://doi.org/10.1046/j.13652745.2003.00742.x

Körner C. 2015. Paradigm shift in plant growth control. Curr. Opin. Plant Bio. 25: 107-114. https://doi.org/10.1016/j.pbi.2015.05.003

Kozlowski TT, Kramer PJ, Pallardy SG \& Roy J. 1990. The Physiological Ecology of Woody Plants. Elsevier Science.

Larson PR. 1967. Effects of temperature on the growth and wood formation of ten Pinus resinosa sources. Silvae Genet. 16: 58-65.

Larson PR. 1994. The Vascular Cambium: Development and Structure. Berlin, Heidelberg, Springer-Verlag, New York. pp. 521-531.

Lewis LN \& McCarty CD. 1973. Pruning and girdling of citrus. In: The citrus industry Vol. III (Reuther, W., Ed.). University of California, Berkeley, USA. 
Liang W, Heinrich I, Simard S, Helle G, Liñán ID \& Heinken T. 2013. Climate signals derived from cell anatomy of scots pine in NE Germany. Tree Physiol. 33: 833-844. https://doi.org/10.1093/treephys/tpt059

Lilleland O \& Brown JG. 1936. Growth study of the apricot fruit. III. The effect of girdling. Proceedings of the J. Am. Soc. Hortic. Sci. 34: 264-71.

Little CH, Sundberg B \& Ericsson A. 1990. Induction of acropetal (14)C-photosynthate transport and radial growth by indole-3-acetic acid in Pinus sylvestris shoots. Tree Physiol. 6: 177-89. https://doi.org/10.1093/treephys/6.2.177

López R, Brossa R, Gil L \& Pita P. 2015. Stem girdling evidences a trade-off between cambial activity and sprouting and dramatically reduces plant transpiration due to feedback inhibition of photosynthesis and hormone signaling. Front. Plant Sci. 6: 285. https://doi.org/10.3389/fpls.2015.00285

Lupi C, Morin H, Deslauriers A \& Rossi S. 2010. Xylem phenology and wood production: Resolving the chicken-or-egg dilemma. Plant, Cell Environ. 33: 1721-1730. https://doi.org/10.1111/j.1365-3040.2010.02176.x

Martin-Benito D, Beeckman H \& Cañellas I. 2013. Influence of drought on tree rings and tracheid features of Pinus nigra and Pinus sylvestris in a mesic Mediterranean forest. Eur. J. For. Res. 132: 33-45. https://doi.org/10.1007/s10342-012-0652-3

MacDougal DT. 1943. The effect of girdling on pines. Am. J. Bot. 30: 715-719.

McDowell NG. 2011. Mechanisms linking drought, hydraulics, carbon metabolism, and vegetation mortality. Plant Physiol. 155: 1051-9. https://doi.org/10.1104/pp.110.170704

Michelot A, Simard S, Rathgeber C, Dufrêne E \& Damesin C. 2012. Comparing the intraannual wood formation of three European species (Fagus sylvatica, Quercus petraea and Pinus sylvestris) as related to leaf phenology and non-structural carbohydrate dynamics. Tree Physiol. 32: 1033-1043. https://doi.org/10.1093/treephys/tps052 
678 Mork E. 1928. Die Qualität des Fichtenholzes unter besonderer Rücksichtnahme auf Schleifund Papierholz. Der Papier-Fabrikant 26: 741-747.

680 Mullendore DL, Windt CW, Van As H \& Knoblauch M. 2010. Sieve tube geometry in relation to phloem flow. Plant Cell Online 22: 579-593. doi: 10.1105/tpc.109.070094

Myers BJ \& Talsma T. 1992. Site water balance and tree water status in irrigated and fertilised stands of Pinus radiata. For. Ecol. Manage. 52: 17-42.

684 https://doi.org/10.1016/0378-1127(92)90494-T

Noel ARA. 1970. The girdled tree. The botanical review 36.2: 162.

Novak K, Čufar K, De Luis M, Sánchez MAS \& Raventós J. 2013. Age, climate and intraannual density fluctuations in Pinus halepensis in Spain. IAWA J. 34(4): 459-474. https://doi.org/10.1163/22941932-00000037

Pacheco A, Camarero JJ \& Carrer M. 2016. Linking wood anatomy and xylogenesis allows pinpointing of climate and drought influences on growth of coexisting conifers in continental Mediterranean climate. Tree Physiol. 36: 502-512. https://doi.org/10.1093/treephys/tpv125

Pellizzari E, Camarero JJ, Gazol A, Sangüesa-Barreda G \& Carrer M. 2016. Wood anatomy and carbon-isotope discrimination support long-term hydraulic deterioration as a major cause of drought-induced dieback. Glob. Chang. Biol. 22: 2125-2137. https://doi.org/10.1111/gcb.13227

697 Plomion C, Leprovost G \& Stokes A. 2001. Wood Formation in Trees. Plant Physiol. 127: 1513-1523. https://doi.org/10.1104/pp.010816

Rathgeber CBK, Rossi S \& Bontemps JD. 2011. Cambial activity related to tree size in a mature silver-fir plantation. Ann.

Bot. 108: 429-438. https://doi.org/10.1093/aob/mcr168 
Rivas F, Fornes F \& Agustí M. 2008. Girdling induces oxidative damage and triggers enzymatic and non-enzymatic antioxidative defences in Citrus leaves. Environ. Exp. Bot. 64: 256-263. https://doi.org/10.1016/J.ENVEXPBOT.2008.07.006

Rossi S, Deslauriers A \& Morin H. 2003. Application of the Gompertz equation for the study of xylem cell development. Dendrochronologia 21: 33-39. https://doi.org/10.1078/1125-7865-00034

Rossi S, Anfodillo T \& Menardi R. 2006. Trephor: A new tool for sampling microcores from tree stems. IAWA J. 27: 89-97. https://doi.org/10.1163/22941932-90000139

Rossi S, Girard MJ \& Morin H. 2014. Lengthening of the duration of xylogenesis engenders disproportionate increases in xylem production. Glob. Chang. Biol. 20: 2261-2271. https://doi.org/10.1111/gcb.12470

Sass U \& Eckstein D. 1995. The variability of vessel size in beech (Fagus sylvatica L.) and its ecophysiological interpretation. Trees 9: 247-252. https://doi.org/10.1007/BF00202014

Savidge RA \& Wareing PF. 1982. Apparent auxin production and transport during winter in the nongrowing pine tree. Can. J. Bot. 60: 681-691. https://doi.org/10.1139/b82-090

Sellin A, Niglas A, Õunapuu E \& Karusion A. 2013. Impact of phloem girdling on leaf gas exchange and hydraulic conductance in hybrid aspen. Biol. Plant. 57: 531-539. https://doi.org/10.1007/s10535-013-0316-2

Sorce C, Giovannelli A, Sebastiani L \& Anfodillo T. 2013. Hormonal signals involved in the regulation of cambial activity, xylogenesis and vessel patterning in trees. Plant Cell Rep. 32: 885-898. https://doi.org/10.1007/s00299-013-1431-4

Sperry JS, Hacke UG \& Pittermann J. 2006. Size and function of conifer tracheids and angiosperm vessels. Am. J. Bot. 93: 1490-1500.

Stone EL. 1974. The communal root system of red pine: growth of girdled trees. Forest Science 20: 294-305. 
Sundberg B, Tuominen H \& Little C. 1994. Effects of the Indole-3-Acetic Acid (IAA) Transport Inhibitors N-1-Naphthylphthalamic Acid and Morphactin on Endogenous IAA Dynamics in Relation to Compression Wood Formation in 1-Year-Old Pinus sylvestris (L.) Shoots. Plant Physiol. 106: 469-476. https://doi.org/10.1104/pp.106.2.469

Sundberg B, Uggla C \& Tuominen H. 2000. Cambial growth and auxin gradients. Cell Mol. Biol. Wood Form. pp. 169-188.

Taylor APC. 2002. The Effect of Stem Girdling on Wood Quality. Wood Sci. Technol. 34: 2012-220.

Thibeault-Martel M, Krause C, Morin H \& Rossi S. 2008. Cambial activity and intra-annual xylem formation in roots and stems of Abies balsamea and Picea mariana. Ann. Bot. 102: 667-674. https://doi.org/10.1093/aob/men146

Tombesi S, Day KR, Johnson RS, Phene R \& Dejong TM. 2014. Vigour reduction in girdled peach trees is related to lower midday stem water potentials. Funct. Plant Biol. 41: 1336-1341. https://doi.org/10.1071/FP14089

Uggla C, Moritz T, Sandberg G \& Sundberg B. 1996. Auxin as a positional signal in pattern formation in plants. Proc. Natl. Acad. Sci. U. S. A. 93: 9282-9286. https://doi.org/10.1073/pnas.93.17.9282

Uggla C, Mellerowicz EJ \& Sundberg B. 1998. Indole-3-Acetic Acid Controls Cambial Growth in Scots Pine by Positional Signaling. Plant Physiol. 117: 113-121. https://doi.org/10.1104/pp.117.1.113

Uggla C, Magel E, Moritz T \& Sundberg B. 2001. Function and Dynamics of Auxin and Carbohydrates during Earlywood/Latewood Transition in Scots Pine. Plant Physiol. 125: 2029-2039. https://doi.org/10.1104/pp.125.4.2029 
van der Werf GW, Sass-Klaassen UGW \& Mohren GMJ. 2007. The impact of the 2003 summer drought on the intra-annual growth pattern of beech (Fagus sylvatica L.) and oak (Quercus robur L.) on a dry site in the Netherlands. Dendrochronologia 25: 103112. https://doi.org/10.1016/j.dendro.2007.03.004

Weinburger JH \& Cullinan FP. 1932. Further studies on the relation between leaf area and size of fruit, chemical composition, and fruit bud formation in Elberta peaches. Proceedings of the Am. Soc. Hortic. Sci. 29: 23-7.

Wiley E \& Helliker B. 2012. A re-evaluation of carbon storage in trees lends greater support for carbon limitation to growth. New Phytol. 195: 285-289. https://doi.org/10.1111/j.1469-8137.2012.04180.x

Wilson BF. 1968. Effect of girdling on cambial activity in white pine. Can. J. Bot. 46: 141146. https://doi.org/10.1139/b68-024

Wilson BF. 1998. Branches versus stems in woody plants: control of branch diameter growth and angle. Can. J. Bot. 76: 1852-1856. https://doi.org/10.1139/b98-156

Wilson BF \& Gartner BL. 2002. Effects of phloem girdling in conifers on apical control of branches, growth allocation and air in wood. Tree Physiol. 22: 347-353. http://dx.doi.org/10.1093/treephys/22.5.347

Wodzicki TJ. 1971. Mechanism of xylem differentiation in Pinus silvestris L. J. Exp. Bot. 22: 670-687. https://doi.org/10.1093/jxb/22.3.670

Zhang J, Nieminen K, Serra JAA, Helariutta Y. 2014. The formation of wood and its control. Current Opinion in Plant Biol. 17: 56-63. ISSN 1369-5266. https://doi.org/10.1016/j.pbi.2013.11.003 
774 Table 1. Meteorological data recorded during the growing seasons of 2014 and 2015 compared with

775 long-term data. $T$ - average air temperature, $P$ - precipitation amount. III-V: March-May period, VI-VIII:

776 June-August period, IX-XI: September-November period. $\Sigma E T$ : the sum of effective temperature at the

777 end of May $\left(\Sigma E T_{1}\right)$, August $\left(\Sigma E T_{2}\right)$ and November $\left(\Sigma E T_{3}\right)$.

\begin{tabular}{|c|c|c|c|c|c|c|c|c|}
\hline Observed period & $\begin{array}{r}\text { Annual } \\
T\left({ }^{\circ} \mathrm{C}\right) \\
\end{array}$ & $\begin{array}{r}\text { Annual } P \\
(\mathrm{~mm}) \\
\end{array}$ & $\begin{array}{r}P I I I-V \\
(\mathrm{~mm})\end{array}$ & $\begin{array}{r}P \text { VI-VIII } \\
(\mathrm{mm}) \\
\end{array}$ & $\begin{array}{r}P|X-X| \\
(\mathrm{mm}) \\
\end{array}$ & $\begin{array}{r}\sum E T_{1} \\
\left({ }^{\circ} \mathrm{C}\right) \\
\end{array}$ & $\begin{array}{r}\sum E T_{2} \\
\left({ }^{\circ} \mathrm{C}\right) \\
\end{array}$ & $\begin{array}{r}\sum E T_{3} \\
\left({ }^{\circ} \mathrm{C}\right) \\
\end{array}$ \\
\hline Long term data & 8.1 & 601.0 & 132.5 & 204.5 & 121.0 & 491.1 & 1759 & 2225 \\
\hline 2014 & 11.3 & 562.6 & 98.2 & 202.4 & 200.0 & 520.9 & 1712 & 2240 \\
\hline \multirow[t]{2}{*}{2015} & 10.0 & 405.6 & 92.0 & 147.0 & 104.2 & 411.1 & 1828 & 2316 \\
\hline & Warmest & Coldest & Highest & Lowest & III-V & VIIVIII & $|X-X|$ & \\
\hline Observed period & month $T\left({ }^{\circ} \mathrm{C}\right)$ & month $T\left({ }^{\circ} \mathrm{C}\right)$ & $P(\mathrm{~mm})$ & $P(\mathrm{~mm})$ & $T\left({ }^{\circ} \mathrm{C}\right)$ & $T\left({ }^{\circ} \mathrm{C}\right)$ & $T\left({ }^{\circ} \mathrm{C}\right)$ & \\
\hline Long term data & Jul (18.1) & $\operatorname{Jan}(-2.7)$ & Jul (82.0) & Feb (27.5) & 9.5 & 18.8 & 9.3 & \\
\hline 2014 & Jul (20.1) & $\operatorname{Jan}(0.7)$ & Sep (119.6) & Feb (14.4) & 10.5 & 17.9 & 10.9 & \\
\hline 2015 & Aug (22.4) & $\operatorname{Jan}(0.7)$ & Aug (69.6) & Apr (6.2) & 8.8 & 20.4 & 9.8 & \\
\hline
\end{tabular}

778

779 
Table 2. Cambial activity and differentiation of xylem and phloem cells timings in the AGA (girdled)

781 and control trees (2014-2015). P-values for the Kruskal-Wallis test ( $\mathrm{H}_{0}$ : Medians of all groups are

782 equal if $p<\alpha(0.05) \Rightarrow$ rejecting $\left.\mathrm{H}_{0}\right)$. DOY: day of year, Control: control trees, AGA: above girdling

783 area, $\Sigma E T$ : sum of effective temperature, $\mathrm{K}-\mathrm{W}$ test: results ( $p$-values) of Kruskal-Wallis test for

784 xylem and phloem cells timings, CA: onset of cambial activity, CCA: cessation of CA, PC: onset of

785 cell enlargement, CPC: cessation of PC, SW: onset of secondary wall thickening, CSW: cessation of

786 SW, MT: occurrence of the first matured tracheids. EP: onset of early phloem formation, LP: onset of

787 late phloem formation and cessation of EP, CLP: cessation of LP. Bold - statistically significant

788 difference (the result of Kruskal-Walis test, $\alpha=0.05$ ).

\begin{tabular}{|c|c|c|c|c|c|c|c|c|c|c|}
\hline \multirow[b]{2}{*}{ Parameters (DOY) } & \multicolumn{5}{|c|}{2014} & \multicolumn{5}{|c|}{2015} \\
\hline & Control & $\begin{array}{r}\sum E T \\
\left({ }^{\circ} \mathrm{C}\right)\end{array}$ & AGA & $\begin{array}{c}\sum E T \\
\left({ }^{\circ} \mathrm{C}\right)\end{array}$ & $\begin{array}{r}\mathrm{K}-\mathrm{W} \\
\text { test }\end{array}$ & Control & $\begin{array}{r}\sum E T \\
\left({ }^{\circ} \mathrm{C}\right)\end{array}$ & AGA & $\begin{array}{r}\sum E T \\
\left({ }^{\circ} \mathrm{C}\right)\end{array}$ & $\begin{array}{r}\mathrm{K}-\mathrm{W} \\
\text { tes }\end{array}$ \\
\hline $\mathrm{CA}$ & $87 \pm 3$ & 77.0 & $80 \pm 3$ & 57.9 & 0.006 & $83 \pm 4$ & 16.8 & $86 \pm 5$ & 29.3 & 0.206 \\
\hline PC & $94 \pm 3$ & 125.3 & $92 \pm 3$ & 107.9 & 0.176 & $108 \pm 7$ & 89.4 & $110 \pm 4$ & 95.8 & 0.601 \\
\hline SW & $115 \pm 3$ & 224.7 & $115 \pm 3$ & 224.7 & 1.000 & $122 \pm 4$ & 175.2 & $132 \pm 4$ & 261.2 & 0.007 \\
\hline MT & $127 \pm 7$ & 309.9 & $126 \pm 6$ & 302.5 & 0.794 & $139 \pm 6$ & 323.6 & $147 \pm 5$ & 375.4 & 0.037 \\
\hline CCA & $277 \pm 14$ & 2025.2 & $261 \pm 6$ & 1906.7 & 0.013 & $226 \pm 7$ & 1574.2 & $190 \pm 8$ & 942.7 & 0.003 \\
\hline CPC & $268 \pm 15$ & 1959.9 & $259 \pm 7$ & 1885.3 & 0.209 & $197 \pm 11$ & 1038.7 & $185 \pm 6$ & 853.5 & 0.042 \\
\hline CSW & $293 \pm 13$ & 2147.4 & $287 \pm 11$ & 2109.6 & 0.417 & $281 \pm 12$ & 2166.3 & $208 \pm 6$ & 1239.0 & 0.003 \\
\hline CA duration (days) & $190 \pm 14$ & - & $181 \pm 5$ & - & 0.132 & $144 \pm 6$ & - & $104 \pm 8$ & - & 0.003 \\
\hline PC duration (days) & $174 \pm 12$ & - & $167 \pm 8$ & - & 0.36 & $89 \pm 11$ & - & $76 \pm 5$ & - & 0.02 \\
\hline SW duration (days) & $177 \pm 11$ & - & $172 \pm 13$ & - & 0.417 & $159 \pm 13$ & - & $76 \pm 8$ & - & 0.004 \\
\hline EP & $88 \pm 4$ & 82.7 & $87 \pm 3$ & 77.0 & 0.523 & $92 \pm 8$ & 30.7 & $96 \pm 4$ & 30.7 & 0.195 \\
\hline LP & $129 \pm 8$ & 327.3 & $123 \pm 6$ & 290.9 & 0.111 & $128 \pm 5$ & 226.6 & $128 \pm 6$ & 226.6 & 0.665 \\
\hline CLP & $181 \pm 14$ & 890.1 & $174 \pm 4$ & 808.3 & 0.082 & $175 \pm 5$ & 708.2 & $158 \pm 4$ & 519.8 & 0.003 \\
\hline EP duration (days) & $47 \pm 10$ & - & $36 \pm 5$ & - & 0.039 & $36 \pm 5$ & - & $32 \pm 4$ & - & 0.434 \\
\hline LP duration (days) & $51 \pm 14$ & - & $50 \pm 7$ & - & 0.655 & $47 \pm 10$ & - & $29 \pm 8$ & - & 0.009 \\
\hline Total duration (days) & $98 \pm 13$ & - & $86 \pm 4$ & - & 0.046 & $83 \pm 12$ & - & $62 \pm 6$ & - & 0.011 \\
\hline
\end{tabular}


791 Table 3. Dynamics of xylem and phloem formation from parameters of the Gompertz function during

7922014 and 2015 in the AGA (girdled) and control trees.

793

\begin{tabular}{lrrrrrr}
\hline & \multicolumn{2}{c}{2014} & & & 2015 \\
\cline { 2 - 3 } \cline { 6 - 6 } Parameters & Control & AGA & & Control & AGA \\
\hline The final number of xylem cells & 38.60 & 34.16 & & 28.33 & 14.00 \\
Daily cell rate of xylem & 0.19 & 0.25 & & 0.25 & 0.22 \\
Maximal daily cell rate of xylem & 0.28 & 0.36 & & 0.36 & 0.32 \\
Day of maximal daily cell rate of xylem (DOY) & 142.344 & 130.11 & & 132.23 & 131.51 \\
Duration of xylem formation (days) & 202.74 & 137.68 & & 114.28 & 64.12 \\
The final number of phloem cells & 11.60 & 11.06 & & 8.92 & 3.81 \\
Daily cell rate of phloem & 0.15 & 0.17 & & 0.12 & 0.05 \\
Maximal daily cell rate of phloem & 0.22 & 0.18 & & 0.17 & 0.08 \\
Day of maximal daily cell rate of phloem (DOY) & 103.69 & 111.33 & & 108.32 & 108.08 \\
Duration of phloem formation (days) & 77.11 & 63.67 & 76.31 & 71.50 \\
\hline
\end{tabular}

794 
795 Table 4. Development of differentiated tracheids according to the Wodzicki algorithm in the AGA

796 (girdled) and control trees. P-values for one-way repeated measures of ANOVA $(\alpha=0.05)$. $\left(\mathrm{H}_{0}\right.$ :

797 Medians of all groups are equal, if $p<\alpha(0.05)=>$ rejecting $\left.\mathrm{H}_{0}\right)$. PC - stage of cell enlargement, SW -

798 stage of secondary wall thickening, MT - stage of tracheid maturation. Control: average values of

799 control trees, AGA: average values of girdled trees from the above girdling area, ANOVA: results ( $p$ -

800 values) of ANOVA test. Bold - statistically significant difference between Control and AGA ( $\alpha=$

$801 \quad 0.05)$.

\begin{tabular}{|c|c|c|c|c|c|c|c|c|c|c|}
\hline \multirow[b]{3}{*}{ Year } & \multirow{3}{*}{$\begin{array}{l}\text { Formed } \\
\text { tracheids }\end{array}$} & \multicolumn{6}{|c|}{ Differentiating xylem } & \multicolumn{3}{|c|}{ PC + SW + MT duration (days) } \\
\hline & & \multicolumn{3}{|c|}{ PC duration (days) } & \multicolumn{3}{|c|}{ SW + MT duration (days) } & \multirow[b]{2}{*}{ Control } & \multirow[b]{2}{*}{ AGA } & \multirow[b]{2}{*}{ Anova } \\
\hline & & Control & AGA & Anova & Control & AGA & Anova & & & \\
\hline \multirow{4}{*}{2014} & $0-25 \%$ & $15.4 \pm 2.7$ & $14.6 \pm 4.4$ & & $17.7 \pm 2.9$ & $17.1 \pm 4.3$ & & $3.0 \pm 1.8$ & $31.7 \pm 1.6$ & 0.137 \\
\hline & $25-50 \%$ & $16.1 \pm 1.0$ & $14.7 \pm 2.1$ & 0.0 & 1.9 & & & & & 0.438 \\
\hline & $50-75$ & $7.6 \pm 1.4$ & $10.6 \pm 2.0$ & 0.002 & & $12.6 \pm$ & & & & 0.012 \\
\hline & $75-100 \%$ & $10.5 \pm 1.3$ & $4.9 \pm 2.5$ & & & & & & \pm 3.0 & 0.003 \\
\hline \multirow{4}{*}{2015} & $0-25 \%$ & $11.0 \pm 1.6$ & $13.2 \pm 2.8$ & 0.1 & 2.1 & $16.0 \pm 2.2$ & 0.1 & & $29.2 \pm 1.4$ & 0.576 \\
\hline & $25-50 \%$ & $9.1 \pm 0.6$ & $13.2 \pm 1.5$ & 0.000 & $18.6 \pm 0.7$ & $12.2 \pm 1.9$ & 0.00 & $27.7 \pm$ & $25.4 \pm 3.1$ & 0.054 \\
\hline & $50-75 \%$ & $10.0 \pm 2.2$ & $7.6 \pm 1.1$ & 0.0 & $15.0 \pm 1.7$ & $8.1 \pm 1.4$ & 0.0 & $25.0=$ & $15.8 \pm 2.0$ & 0.002 \\
\hline & $75-100 \%$ & $2.9 \pm 2.2$ & $5.6 \pm 2.7$ & 0.104 & $9.4 \pm 0.8$ & $13.0 \pm 5.3$ & 0.103 & $12.3 \pm 2.7$ & $18.5 \pm 2.6$ & 0.005 \\
\hline
\end{tabular}

802

803 
804 Table 5. Descriptive statistics of morphometric parameters in the AGA (girdled) and control trees for

805 xylem tracheids (2014-2015). C: control trees, AGA: above girdling area, EW - earlywood tracheids,

806 LW - latewood tracheids, RD - radial dimension, LD - lumen diameter, 2CW - double cell-wall

807 thickness. AVG: average value, SD: standard deviation, N: number of measured items. Bold -

808 statistically significant difference between C and AGA $(\alpha=0.05)$. Units $-\mu \mathrm{m}$.

\begin{tabular}{|c|c|c|c|c|c|c|c|c|c|c|c|c|}
\hline \multirow[t]{3}{*}{2014} & \multicolumn{6}{|l|}{ EW } & \multicolumn{6}{|l|}{ LW } \\
\hline & \multicolumn{2}{|l|}{$\mathrm{RD}$} & \multicolumn{2}{|l|}{ LD } & \multicolumn{2}{|l|}{$2 \mathrm{CW}$} & \multicolumn{2}{|l|}{$\mathrm{RD}$} & \multicolumn{2}{|l|}{ LD } & \multicolumn{2}{|l|}{$2 \mathrm{CW}$} \\
\hline & $\mathrm{C}$ & AGA & $C$ & AGA & $C$ & $\overline{A G A}$ & $C$ & AGA & $C$ & AGA & $\mathrm{C}$ & AGA \\
\hline AVG & 37.5 & 36.0 & 32.4 & 31.1 & 5.0 & 4.9 & 21.3 & 20.9 & 13.0 & 13.9 & 8.2 & 6.4 \\
\hline SD & 9.1 & 10.8 & 9.4 & 10.8 & 1.0 & 1.0 & 7.5 & 6.6 & 6.9 & 6.9 & 2.9 & 2.3 \\
\hline $\mathrm{N}$ & 279 & 401 & 279 & 401 & 279 & 401 & 267 & 326 & 267 & 326 & 267 & 326 \\
\hline 2015 & & & & & & & & & & & & \\
\hline AVG & 37.2 & 25.8 & 32.8 & 22.2 & 4.4 & 3.6 & 14.5 & 10.7 & 8.9 & 6.1 & 5.4 & 4.3 \\
\hline $\mathrm{SD}$ & 8.8 & 7.9 & 9.0 & 7.8 & 1.0 & 0.8 & 3.9 & 1.0 & 3.5 & 0.9 & 1.6 & 0.1 \\
\hline $\mathrm{N}$ & 320 & 279 & 320 & 279 & 320 & 279 & 117 & 4 & 117 & 4 & 117 & 4 \\
\hline
\end{tabular}

809 
810 Table 6. Descriptive statistics of morphometric parameters in the AGA (girdled) and control trees for

811 phloem cells (2014-2015). C: control trees, AGA: above girdling area, EP - earlyphloem, LP -

812 latephloem, $\mathrm{RD}$ - radial dimension, $\mathrm{LD}$ - lumen diameter, $2 \mathrm{CW}$ - double cell-wall thickness. AVG:

813 average value, SD: standard deviation, N: number of measured items. Bold - statistically significant

814 difference between $\mathrm{C}$ and AGA $(\alpha=0.05)$. Units $-\mu \mathrm{m}$.

\begin{tabular}{|c|c|c|c|c|c|c|c|c|c|c|c|c|}
\hline \multirow{3}{*}{2014} & \multicolumn{6}{|l|}{ EP } & \multicolumn{6}{|l|}{ LP } \\
\hline & \multicolumn{2}{|l|}{$\mathrm{RD}$} & \multicolumn{2}{|l|}{ LD } & \multicolumn{2}{|l|}{$2 \mathrm{CW}$} & \multicolumn{2}{|l|}{$\mathrm{RD}$} & \multicolumn{2}{|l|}{ LD } & \multicolumn{2}{|l|}{$2 \mathrm{CW}$} \\
\hline & C & AGA & C & AGA & C & AGA & C & AGA & C & AGA & C & AGA \\
\hline AVG & 20.3 & 19.4 & 18.7 & 17.9 & 1.5 & 1.4 & 23.4 & 21.2 & 21.9 & 19.8 & 1.5 & 1.4 \\
\hline SD & 5.0 & 5.1 & 5.1 & 5.2 & 0.3 & 0.2 & 4.5 & 4.8 & 4.4 & 4.8 & 0.4 & 0.3 \\
\hline $\mathrm{N}$ & 214 & 127 & 214 & 127 & 214 & 127 & 50 & 55 & 50 & 55 & 50 & 55 \\
\hline \multicolumn{13}{|l|}{2015} \\
\hline AVG & 21.4 & 18.9 & 19.9 & 17.5 & 1.5 & 1.3 & 21.6 & 19.6 & 20 & 18.2 & 1.5 & 1.3 \\
\hline SD & 5.3 & 4.9 & 5.4 & 4.9 & 0.3 & 0.3 & 5.5 & 6.0 & 5.5 & 5.9 & 0.3 & 0.3 \\
\hline $\mathrm{N}$ & 118 & 78 & 118 & 78 & 118 & 78 & 42 & 18 & 42 & 18 & 42 & 18 \\
\hline
\end{tabular}

815

816 
817 Table 7. Summary of one-way repeated measures ANOVA of morphometric parameters in six control

818 and six girdled (AGA) trees (2014-2015). P-values for ANOVA test ( $\mathrm{H}_{0}$ : Medians of all groups are

819 equal, if $p<\alpha(0.05) \Rightarrow$ rejecting $\left.\mathrm{H}_{0}\right)$. C: control trees, AGA: above girdling area. Bold - statistically

820 significant difference $(\alpha=0.05)$.

\begin{tabular}{|c|c|c|c|c|c|c|}
\hline \multirow[b]{2}{*}{ Anatomical variable } & \multicolumn{2}{|c|}{ Type (C/AGA) } & \multicolumn{2}{|c|}{ Year (2014/2015) } & \multicolumn{2}{|c|}{ Type* Year } \\
\hline & $\mathrm{F}$ & $p$ & $F$ & $p$ & $F$ & \\
\hline Number of tracheids & 0.11 & 0.738 & 34.356 & 0.000 & 6.800 & 0.011 \\
\hline Number of earlywood tracheids & 0.71 & 0.403 & 3.239 & 0.077 & 4.744 & 0.033 \\
\hline Number of latewood tracheids & 0.24 & 0.624 & 17.965 & 0.000 & 0.931 & 0.339 \\
\hline The radial dimension of earlywood tracheids & 146.69 & 0.000 & 97.387 & 0.000 & 86.034 & 0.000 \\
\hline The radial dimension of latewood tracheids & 1.50 & 0.221 & 24.926 & 0.000 & 0.920 & 0.338 \\
\hline The radial dimension of the lumen in earlywood tracheids & 123.20 & 0.000 & 63.214 & 0.000 & 76.070 & 0.000 \\
\hline The radial dimension of the lumen in latewood tracheids & 0.30 & 0.585 & 12.936 & 0.000 & 1.290 & 0.256 \\
\hline Double cell-wall thickness of earlywood tracheids & 84.76 & 0.000 & 285.840 & 0.000 & 49.567 & 0.000 \\
\hline Double cell-wall thickness of latewood tracheids & 0.92 & 0.339 & 10.578 & 0.001 & 0.042 & 0.837 \\
\hline Number of sieve cells & 3.29 & 0.074 & 14.120 & 0.000 & 41.975 & 0.000 \\
\hline Number of early sieve cells & 0.56 & 0.458 & 1.162 & 0.285 & 34.653 & 0.000 \\
\hline Number of late sieve cells & 7.09 & 0.010 & 39.798 & 0.000 & 16.528 & 0.000 \\
\hline The radial dimension of early sieve cells & 22.01 & 0.000 & 0.397 & 0.529 & 0.076 & 0.784 \\
\hline The radial dimension of late sieve cells & 5.86 & 0.017 & 3.956 & 0.048 & 0.027 & 0.869 \\
\hline The radial dimension of the lumen in early sieve cells & 18.99 & 0.000 & 0.182 & 0.670 & 0.129 & 0.720 \\
\hline The radial dimension of the lumen in late sieve cells & 5.34 & 0.022 & 4.206 & 0.042 & 0.043 & 0.835 \\
\hline Double cell-wall thickness of early sieve cells & 28.65 & 0.000 & 4.521 & 0.034 & 0.362 & 0.548 \\
\hline Double cell-wall thickness of late sieve cells & 5.34 & 0.022 & 4.206 & 0.042 & 0.043 & 0.835 \\
\hline
\end{tabular}

821 
823 Figure 1. Scheme of morphometric cellular parameters measurements. EW: earlywood zone, LW:

824 latewood zone, CW: cell-wall, 2CW: double cell-wall thickness, L: lumen radial dimension, R: an 825 entire radial dimension of tracheid. Scale bar: $50 \mu \mathrm{m}$.

827 Figure 2. Weather data and soil water potential recorded during the growing seasons of 2014 and 828 2015. a \& b - daily precipitation amount (bars) and average daily air temperature (solid line). c \& d 829 average daily soil water potential (solid line) and the sum of effective temperature (dashed line). DOY

830 - the day of the year (70: March 11, 100: April 10, 130: May 10, 160: June 9, 190: July 9, 220:

831 August 8, 250: September 7, 280: October 7, 310: November 6).

832

836

Figure 3. The xylem and phloem cell formation and structure of fully formed tracheids during one growing season. $\mathrm{a}$ - phase of dormancy, $\mathrm{b}$ - activated cambial zone and occurrence of the new phloem cells, $\mathrm{c}-$ all differentiation phases of newly forming xylem and phloem cells in the last week of June 2014, d - distinguished glistening secondary cell-walls under polarized filter, e - formation of intraannual density fluctuation (IADFs) after reactivated cambial zone (caused by precipitation episode) in mid-September 2014 and fully formed phloem annual ring, f \& g-occurrence of the earlywood-like tracheids in latewood zone in both of defined types (IADFs $L$ and IADFs $L^{+}$). AP -axial parenchyma, $\mathrm{CC}$ - cambial cells, $\mathrm{CP}$ - collapsed phloem cells of previous years, $\mathrm{EP}$ - early phloem cells, LW - latewood tracheids, LP - late phloem cells, MT - fully matured xylem cells (tracheids), $\mathrm{PC}$ - phase of cell enlargement, pLP - late phloem cells of previous year, PZ - phloem zone, SW phase of secondary cell-wall thickening. IADFs - intra-annual density fluctuation with earlywoodlike tracheids in latewood zone of two types (IADFs $L$ and IADFs $L^{+}$) according to Campelo et al. (2007). The displayed scale bars: $\mathrm{a}-50 \mu \mathrm{m} ; \mathrm{b}, \mathrm{c}, \mathrm{d}, \mathrm{e}, \mathrm{f}, \mathrm{g}-100 \mu \mathrm{m}$.

Figure 4. Fully formed annual rings and IADFs structure of control and girdled trees during the growing seasons 2014 and 2015. a - formed annual ring of control tree with "IADFs $L$ " in 2014, b - 
formed annual ring of girdled tree with "IADFs $L$ "and "IADFs $L^{+}$“ in 2014, c - formed annual ring of

850 control tree with "IADFs $L^{+}$” in 2015, d - annual ring of girdled tree with no occurrence of latewood

851 zone in 2015, e \& f - frequency of IADFs formed annual rings of the last five years period (2011-

852 2015) in control (E) and girdled (F) trees. CC - cambial cells, EW - earlywood zone, LW - latewood

853 zone, $\mathrm{PZ}$ - phloem zone. IADFs - intra-annual density fluctuation with earlywood-like tracheids in

854 latewood zone of two types (IADFs $L$ and IADFs $L^{+}$) according to Campelo et al. (2007). The

855 displayed scale bars: a, b, c, d- $100 \mu \mathrm{m}$; e \& f- $400 \mu \mathrm{m}$.

856

857 Figure 5. Dynamics of cambial activity, xylem and phloem cells' development fitted to Gompertz

858 function during the growing seasons of 2014 and 2015. The number of cells within the cambial zone

859 (a, b), in the PC phase (c, d), in the SW phase (e, f), in the MT phase $(\mathrm{g}, \mathrm{h})$, total cell number within

860 fully formed annual increment $(i, j)$. The number of cells in the EP phase $(k, 1)$, in the LP phase $(m, n)$,

861 total cell number within fully formed annual increment $(o, p)$. Total cell increment according to

862 Gompertz function and weekly cell rate of xylem and phloem cells (q, r, s, t). Control trees - solid

863 line with black circles, AGA (above girdling area) - solid line with white circles. Bell shaped curves -

864 weekly cell rate, S-shaped curves - Gompertz function. DOY - the day of the year (70: March 11,

865 100: April 10, 130: May 10, 160: June 9, 190: July 9, 220: August 8, 250: September 7, 280: October

866 7, 310: November 6). Vertical solid lines - standard errors. Vertical dashed lines - the month of the

867 year. M, A, M, J, J, A, S, O, N-months in order.

868

869 Figure 6. Development of differentiated tracheids during the years 2014 and 2015 according to

870 Wodzicki algorithm in the AGA (girdled) and control trees. Empty stripes - phase of cell enlargement

871 (PC), grey stripes - phase of secondary cell-wall thickening and maturation (SW + MT), (n) -

872 tracheids order. a - differentiated tracheids of control trees during 2014, b - differentiated tracheids of

873 AGA during 2014, c - differentiated tracheids of control trees during 2015, d - differentiated tracheids

874 of AGA during 2015. 
875 Figure 7. Xylem and phloem cells' dimensions measured in 2014 and 2015. Double cell-wall thickness

876 of tracheid ( $a$ \& b), the radial dimension of tracheid ( $c \& d$ ), the double cell-wall thickness of sieve

877 cell (e \& f) and radial dimension of sieve cell ( $\mathrm{g} \& \mathrm{~h}$ ). Control trees - black curve (line) and black

878 circles, AGA (above girdling area) - gray curve (line) and white circles. 